\title{
它迎只A
}

Article

\section{'The blind leading the blind' - A reflection on coaching blind football}

\author{
David Mycock ${ }^{1 *}$ and Győző Molnár ${ }^{1}$ \\ Received: $8^{\text {th }}$ October 2019, Accepted: $25^{\text {th }}$ August 2020; Published: 26 $6^{\text {th }}$ November 2020
}

\begin{abstract}
There are well-established links between successful athlete development, retention and high-quality coaching. Such links between athletes and coaches are also pertinent in disability sports. However, there is limited knowledge around coaching and coaches' needs and barriers in disability sport. To bridge this gap, a self-narrative approach was employed covering a 5-year period of the first author's career of coaching Blind (B1) and Visually Impaired (VI) football. This personal account provides a narrative, which identifies a range of key issues around the challenges of coaching practice in adapted football. Personal stories are presented through realist tales, which are grounded in the first author's lived experiences. Particular attention is paid to infrastructural challenges, which are evident in VI/Blind football. Based on the narratives presented, we reflect on the field-specific issues in B1 and VI football and make recommendations for practitioners.
\end{abstract}

Keywords: Visual impairment, player - coach relationships, parasport, disability

\section{Introduction}

It is estimated that there are between 13.3 and 13.9 million disabled people in the United Kingdom (UK), which equates to $22 \%$ or one in five of the country's population at an annual care cost of £2.1 billion (Disability Living Foundation, 2019; Papworth Trust, 2019; Scope, 2019). The European Commission (2020) estimates that one in six people in the EU have a disability, which is equivalent to 80 million people. Of that figure, 30 million people are blind or partially sighted, according to the European Blind Commission (2020). People with a disability may experience reduced access to areas such as sport, which can have a detrimental effect on their quality of life (American College of Sports Medicine, 2016). This is supported by the Sport England (2017) Active Lives Adult Survey, which found that $43 \%$ of people with a disability remain physically inactive. Limited access coupled with social stereotypes around disability are arguably the main reasons as to why the growth of elite level disability sports have exhibited snail-paced progress. However, it is now recognised that athletes with a disability can compete in high performance sports, which parallels their able-bodied peers (Brittain, 2004; Kasser \& Lytle, 2013; Le Clair, 2011). Consequently, in the UK there are now 6,00o people with disabilities who have been trained as sports coaches (Disability Sports Coach, 2018).

Coaches are critical in athletes' sport engagement. A quarter of people who participate in sport claim that they are more likely to remain engaged with a motivated coach (Sports Coach UK, 2017). The increasing need for coaches is reflected in the number of people beginning a career in coaching. It is estimated that there are 3.6 million sports coaches in the UK working with over seven million participants (Sports Coach UK, 2017). 
However, coaching in disability sport has displayed a different development trajectory. Hedrick, Morse and Figoni (1988) found in the 1980s that even at elite level only a minority ( 2 out of 17) of male wheelchair road-racers had a coach. Later, Ferrara and Buckley (1996) indicated that only $58 \%$ of the 319 American elite athletes had coaches during their training for the 1992 Paralympics. More recently, Martin and Whalen (2014) noted that disabled players and athletes primarily coach themselves and, thus, there appears a continuous, general absence of coaches in disability sports. This is specifically true in relation to blind football where there have been only 2 to 3 dedicated coaches at any level between 2003 and 2018 and between 3 to 6 recognised blind football teams across the UK (English Football Association, 2011). The number is markedly different when compared to Sports Coach UK (2017) figures stating that there are 3.6 million adults in coaching roles in able-bodied sports.

Nevertheless, the sheer presence of a coach may not be sufficient. The English Federation for Disability Sport (2018) state, a critical factor for athletes' growth is exposure to good coaching practices, styles, and philosophies. This is of importance for athletes with disabilities (Martin, 1999) as this area of coaching, in most cases, significantly differs from coaching able-bodied athletes and, hence, requires specific skills and knowledge. Wareham, Burkett, Innes, and Lovell (2017) found that able-bodied coaches in the disability sport sector were regularly confronted with difficulties not generally faced by coaches of nondisabled athletes such as: lack of accessibility, lack of knowledge and negative preconceptions.

In relation to lack of knowledge, Lenney and Sercombe (2002) explain that it is common for non-disabled people to refrain from interacting with those with a disability to avoid being 'impolite', which might be a reason for the present lack of able-bodied coaches in and understanding of disability sports. Davey (2014, p.2) described this phenomenon as a 'fear of the unknown', or a general concern towards a 'massive learning curve' required for coaches' development in para sports. Such accounts are reinforced by the first author's personal observations regarding the challenges experienced in VI/Blind football, which will be explored later.

Generally, successful coaching of athletes requires fundamental skills such as providing appropriate feedback, setting realistic goals and developing skill progressions, etc. (Cross \& Lyle, 2006; Kasser \& Lytle, 2013; Schmidt \& Wrisberg, 2014). However, there are training skills and knowledge that are specific to coaching athletes with a disability, such as: recognising needs for biomechanical adaptations as suggested by Giagazoglou, Katis, Kellis \& Natsikas (2011) who found significant kinematic differences in kicking actions between blind and sighted players. Morato (2007) also notes differences between training ablebodied and disabled athletes in relation to balance, spatial orientation and psychomotor behaviour, as well as learning about the game at both attacking and defending levels (see also Farias, Oliveira, Gonçalves, \& Sória, 2008; Morato, Gomes, Duarte, \& De Almeida 2011).

Therefore, understanding athletes' abilities and their impairment specific individual needs is of paramount importance (DePauw \& Gavron, 2005; Young 2010). Despite the complexity of coaching athletes with a disability, McMaster, Culver and Werthner (2012) acknowledge that research into this area is limited, which does not assist current coaches to learn from and reflect on previous examples. When coaches are aware of the barriers and challenges disabled athletes face, they can implement strategies to mitigate disadvantageous circumstances by, e.g., increasing accessibility to sports, obtaining specialist equipment, and understanding the individual needs of their athletes. Given the lack of existing literature in the area of disability sports coaching, especially in relation to coaches' experience in the field, and that research regarding 5 -a-side football for the blind has only recently come to the fore 
(see Gamonales, León, Muñoz, González-Espinosa \& Ibáñez, 2018), our main goal with this article is to raise awareness of some of the challenges disability sports coaches may face during their career. In addition, this work is also informed by the fact that people with sensory impairments (hearing and visual impairments) historically have the lowest levels of sports participation, exposure to good coaching and involvement in high intensity physical activity (British Blind Sport, 2017; Kobberling Jankowski, \& Leger, 1991; Macbeth 2009; Ponchillia, Powell, Felski, \& Nicklawski, 2005; Short \& Winnick 1986). In light of the above, here we have elected to employ a self-narrative approach to identify and explore some of the key coaching-related challenges in VI football.

\section{Self-narrative: The past and its reflections}

To contribute to existing knowledge and to reflect on coaching experiences in VI/Blind football, we used personal recollection-based narratives, covering the initial 5 years of the first author's engagement with the sport. The chief reason for adopting this approach is to capture some of the key challenges the first author experienced while transitioning from able-bodied to VI football. Whilst multiple accounts have scrutinised self-narrative-based inquiry (e.g., see Elliott, 2006), Robyn (2009) endorsed how writing from a personal perspective can be a useful research tool for exploring coaching journeys through life by understanding the complexities of coaches' social worlds. We would support Robyn's (2009) observation and further argue that this approach has merits (Carrington, 2008), as it is a process by which 'individuals translate knowledge into telling' (Elliott, 2005). We would contend that one of the merits of adopting a self-narrative approach is to recognise, ponder on and publicly share ongoing social issues within the area of focus (e.g., Peers, 2012; Stewart, 2016). While the individuals', around whom the research is centred, perceptions may not be generalizable in the traditional, post-positivist sense, the personal troubles identified may be relatable to others' experiences actively involved in the field of study and/or practice for we view our own external world 'from a centre lying within ourselves' (Polanyi, 1970).

The personal account presented here, therefore, provides a rich, narrative-style insight, which identifies and explores a range of issues around coaching in VI/Blind football and the first author's encounter with, transition to and experience in disability sports. Personal stories are presented through realist tales (King, 2019), which are grounded in real events and people's lived experiences. The self-reflection presented here also draws upon recollections of accounts from games organisers, discussion with other coaches, support staff, and players, revisiting old photographs, team meeting minutes and media interviews. In the sections below, these accounts are presented as integrated story lines, fused with relevant literature and conceptual insight.

\section{VI/Blind football: A brief overview}

VI/Blind football, similar to other disability sports, does not have a history as deeply rooted in British society as able-bodied sports, however, we would argue it pertinent to introduce its brief history at this juncture. British Blind Sport was formed in November 1975 under the name of British Association of Sports and Recreation Activities of the Blind (BASRAB) (Macbeth, 2009). In 1976 British Blind Sport (BBS) became a registered charity whose aim was to ensure that people living with sight loss had the same opportunities to access and compete in physical activity or sport as fully sighted people (British Blind Sport, 2019). The first organised football opportunities for partially sighted individuals in Britain took place in 1980 and were initiated by the British Football Association for the Visually Impaired (BFAVI). The BFAVI operated a national league independently until 1997 when the sport was linked with the BBS. In 1998, the national league was further supported by the 
formation of the English Federation for Disability Sport (EfDS) and in 1999 by the English FA (British Blind Sport, 2019; English Federation for Disability Sport, 2019; Football Association; 2019; Macbeth 2009). Currently, there are numerous pan-disability organisations which provide opportunities to play football in the UK through the Special Olympics, BBS, The FA Ability Counts Leagues, and Great Britain Disability Football Association and the Paralympic Games (Football Association, 2019).

The year of 1996 was pivotal for VI football development in England. This was the year when ex-professional football player, Tony Larkin, unofficially began developing blind football at the Royal National College for the Blind (RNC) in Hereford and, through selffunding, represented England at the 1997 European Championships in Barcelona and achieved third place (Royal National College for the Blind, 2019; Football Association, 2019). With Larkin as Head Coach, the England team were runners up at the next six European Championships before coming third again at the 2011 Championship in Aksaray in Turkey where the first author served as Assistant Coach. However, despite some initial success, the sport's national development was slow.

There are several differences in the organisation of B1 (total blind), 5-a-side football and VI football (soccer) or futsal as it is sometimes known. Although the International Blind Sports Association (IBSA) govern both sports and determine the competition structures and cycles, the B1 version (almost or total blind with minimal light perception) is a Paralympic Sport (International Paralympic Committee, 2019) while the VI game, which allows for B2, B3, B4 and B5 medically classified players to play together in one team, is not (International Paralympic Committee, 2019). This difference has led to imbalances in financial investment. For instance, in October 2014 Sport England and the English FA announced to invest $£ 1.3$ million into Blind Football in England over the next two years (FA, 2012). The FA's move to provide full-time professional contracts for the staff and players has been pivotal in advancing the quality of the England and Great Britain national B1 football teams as they have been consistent finalists and semi-finalists in IBSA tournaments and are currently ranked 9th in the world (International Blind Sports Association, 2019). Although the grassroots version of the game in the UK is largely underdeveloped, there are currently only three official blind teams competing in the National League from the FA, Centres of Excellence (Football Association, 2019). In other words, in the UK it has taken from 1975 to 2014 to establish a semi-sustainable version of the game of football for people who are total blind or VI. This slow-paced development of the adapted version of football may be viewed as an indication of the numerous challenges players and coaches involved in Blind/VI football have faced. Some of the above-outlined challenges we explore through the first author's experience in coaching VI/Blind football below.

\section{Playing the blind school? A journey of self-(re)discovery}

A journey of self-discovery through an exploration of one's own subjectivity of the 5 senses can provide a chance to develop new boundaries and horizons, especially in the under-represented coaching environment of sports such as blind football (Sugden \& Tomlinson, 2002; Willis \& Trondman, 2000). Having been a professional football player in the English Football Leagues and having coached mainly 11-a-side Association Football, I was somewhat surprised when asked in 2003 if I were interested in coaching blind football. Given that I had limited previous knowledge of VI football, my first, genuinely surprised reaction was: 'This must be some kind of a joke!' My initial thoughts harked back to my school years in the north of England where my footballing career began in the 1970s. At that time if a team beat the opponent excessively, a common football related gibe was to ask: 'Who were you playing? The blind school?' Given my lack of acquaintance with disability sports at that time, when asked the question about coaching VI football, I expected a similar 
quip. Instead, a realisation began to emerge that the question was serious and, I later learned, so was the VI version of the 'beautiful game'.

In addition to the broad social stereotypes reinforced by the dominant medical model of disability (Houlihan \& Malcolm, 2016), I was also affected by a vivid and emotional personal image of disability. When I was 7-year-old, my Grandfather accidentally tripped in his own house and then spent the next 2 years bed-ridden in a specialist spinal unit fighting for his life. The outcome of his injuries rendered him quadriplegic and spent the rest of his life in a wheelchair. Adapted equipment, transport challenges, lifestyle changes, disapproving public perceptions and sensitive family dynamics, along with invasive procedures by nurses, home carers and random visits by the caring community all became part of life. These experiences jointly led to the creation of my perception of disability and, thus, for a while I struggled to see how sport, especially elite sport, and disability may be connected. Interestingly, it was also this early exposure to disability, which normalised it and consequently helped me overcome my prejudices, leading to one of the best footballing periods of my life.

\section{Getting engaged with VI football}

I began working in VI football as a part time, paid coach through the Talented Athlete Scholarship Scheme (TASS). The player I began to coach was on the brink of becoming England and Great Britain Blind (B1) football team captain after being involved in the sport for 4 years. The player was medically classified as B1 (total blind) and had a genetic congenital condition. However, during training there was no focus on the physical disability. Indeed, the ' $\mathrm{D}$ ' word was not mentioned. My relationship with the athlete started well and quickly deepened as we had football as common denominator as well as the shared experience of being 'northerners' (from north of England) at a Southern English University. Fortier (2000) recognised the bond that can developed between migrants when they share the same geographic space away from home. In a similar vein, 'being away from home' as well as our mutual cultural background, shared geographic local and love for football overrode the limited, but pervasive ability-disability dichotomy.

It became clear from the outset that the challenge would not be exclusive to overcoming the ability-disability dichotomy but would also include negotiating the lack of infrastructure in VI football. For instance, we did not have an audible ball, which is essential to play the game. To remedy this, we made joint efforts to 'fashion' our own audible ball by putting small ball bearings from a toy into a 'standard football' through the valve opening. We laughed as we tried forcing the small metal ball bearings inside the football. Our commitment to training and 'making-it-work' further developed our relationship and we began to have a positive impact on each other. For instance, the player's skills and commitment significantly increased my appreciation of and respect for VI football. It is noted that coaches who have a positive impact on athletes engage in effective behaviour, which can result in successful performance and positive psychological outcomes such as high perceived ability, self-esteem and enjoyment (Horn, 2002; Weinberg \& Gould, 2019). This was clearly the case here as my relationship with the player developed so did my connection to and respect for VI/Blind football.

\section{Challenges of Coaching Blind/VI Football}

Infrastructural challenges were the general state of the game in the early 2000s, some of which was completely unheard of in able-bodied football. For instance, one of the initial main barriers was sourcing essential equipment such as an audible football. Audible footballs (anecdotally made by Brazilian prisoners) were hard to secure and, thus, at the outset we tried to make our own (as mentioned above). After multiple failed attempts, we 
decided to turn to some of the existing, informal VI football networks in the UK and a couple of weeks later we had footballs, which allowed us to begin training.

Another challenge was the different coaching style I had to adopt in VI football, which was fundamentally dissimilar to coaching in mainstream football. For instance, in addition to the regular and traditional coaching duties such as physical trainer, mentor and tactician, my coaching roles increased to also include: educator, guide, pastoral and business manager aspects (International Council for Coaching Excellence, 2012). The International Council for Coaching Excellence (International Council for Coaching Excellence, 2012, p.4) claimed that "Coaching is in its most dynamic era in history as the role is working with increasingly diverse populations and face heightening demands from their athletes, parents, administrators and fans". This ICCE report was published almost 10 years after I first became introduced to blind football, but it accurately reflects the complexity of my coaching role in VI football. However, for me, at least initially, this support role was unexpected and challenging to assume. It required a significant paradigm shift in my coaching practice and philosophy as I had previously followed the traditional model of British-based coaching style, which basically meant looking after the physical and technical aspects of the players, the delivery of training sessions, and the design of tactics and strategies for the team (Hughes 1980; Wade 1967). In essence, coaching VI/Bind football required not only a different, but a greater level of personal involvement.

After 5-a-side B1 football became a recognised Paralympic sport in 2004, a noticeable development began and the sport emerged as a viable career option for players and coaches' alike (International Blind Sports Association, 2019). As my player was at elite level, he was given access to sport science and medical support, which positively affected his performance. As mentioned above, disability sport coaches often find themselves performing many of the same tasks as able-bodied sport coaches as well as experiencing additional challenges unique to each athlete and sport (Townsend et al., 2019; Allan, Blair-Evans, Latimer-Cheung \& Cote, 2019). However, the major difference I found with coaching blind players was that I had to have detailed knowledge of the physical environment.

For instance, it was pertinent to know the layout of and be able to navigate the changing rooms, ways to the playing area and the playing area itself. I had to carefully check and monitor spaces the players occupied for unexpected objects that could become potential 'silent assassins' by obstructing players' pathways. I also had to take note of things like the position of the sun or floodlights and the general quality of light and level of noise (Collins \& Kay, 2003). That is, coaching Blind/VI football required additional time, effort, and financial costs to ensure I, as the coach, appropriately looked after the players in my care. Consequently, the actual coaching of football at times was only the 'tip of the iceberg' as I was undertaking a much more extensive coaching/caring role. In other words, my actual and expected roles and responsibilities differed greatly.

Studies show that para sport coaches encounter factors that are unique to working with athletes with disabilities (Tawse, Bloom, Sabiston \& Reid, 2012; Davey 2014). Tawse et al. (2012) found that wheelchair rugby coaches held a multitude of responsibilities in addition to their coaching duties, which they performed in able-bodied sports. They noted that such responsibilities included: training for spatial orientation (individual and team orientation) (Campos, 2000); providing directions through style and tone of voice (Matsui, 2007; Campos et al., 2013) and catering for the kinematic differences in kicking between blind and sighted players (Giagazoglou, Katis, Kellis \& Natsikas, 2011). As the above examples indicate, my coaching role reached beyond what is 'normally' expected and involved being a mentor, leader, guide, navigator, driver, communicator, support worker, toilet assistant, waiter, proof reader, critical friend and chaperone, to name but a few. 
The solo sport aspect of training VI football was also a challenge. Traditional football coaching is aimed at organising players together to work as a unit. However, blind football often requires a one-person-centred style of playing and, thus, a matching coaching style. The best players in the world are masters at going 'solo' on the pitch. They are not as reliant on their team mates as traditional 11-a-side association football players and it is each player's own individual skills which set the game of blind football apart from any other invasion team sport. Consequently, my practice had to change rapidly as I began to gain more understanding of what it was like to function and play football in a 'world of blindness'.

\section{Overcoming ocular and coach centrism}

As the player I coached was congenitally blind, he developed an exceptional level of spatial awareness. He could 'read' people, places, spaces, and objects. He was in tune with his senses much more than my ocular-centric self. He had learned and acquired many abilities by having to intelligently adapt his life skills around a visual-centred world. The smells, noises, atmosphere and excitement of the pre-and post-match stories and feelings all became a powerful set of natural tools, which developed his ability to comprehend and read the complex patterns of play and surrounding environment. As a consequence of the player's own way of understanding and 'reading' the game, I had to develop different approaches to coaching football that included tactile information giving such as writing shapes on hands and body, and identifying landmarks to support verbal explanations. To this effect, I designed an embossed raised, tactile marker board to simulate activities, shapes, and movement patterns.

In addition, I learnt new and effective ways of using my body and voice to communicate with the player, which is a central skill for success when working with blind people (Macbeth 2009; Football Association, 2019). For instance, using a range of whistles, clicks, calls, volumes, and tones prompted me to understand human echolocation. Echolocation has been found by many studies on both animals and humans to provide a better array and level of audio feedback (Davies, Pinder \& Burners, 2009; Fister, Rauter, Xin-She, Ljubic, \& Fister, 2015; Fister, Fister, \& Fister, 2019; Fister et al, 2019). Receiving information through echolocation helps VI people avoid obstacles whilst undertaking mobility training when learning to navigate with the white walking canes and sticks (Royal National Institute for the Blind, 2019). This is a strategy VI/Blind football players frequently use and was a central part of my player's orientation skills.

Through trial and error, I soon realised that coaching people with VI required me to become a fully active part of each training session. I did not and could not verbally instruct from the side-line as it happened and still happens in traditional football coaching (Reilly, 2008), as that did not work in VI/Blind football. For instance, as I was required to play multiple roles, I had to be creative to simulate functions and phases of play as well as orchestrating match play scenarios. In doing so, I was guided by Mosston \& Ashworth's (1986) 'Spectrum of Learning Model' and, thus, where possible I used guided discovery to help players' 'semi-self-administer' their own fitness and game sense through play practice to evolve their intrinsic learning (Pill, 2012).

This also strengthened players' resolve and awareness of themselves and of others, which helped them engage with the teaching games for understanding model of learning (TGfU). TGfU has been noted to be one of the most effective methods of learning how to play games (Cushion, 2013;Thorpe, Bunker \& Almond, 1986). It has been explained that "a coach technique centred approach ensures a large percentage of learners achieve little success due to the emphasis on performance, which can promote inflexible techniques and poor decision making capacities in sports players who are over reliant on their coach" (Bunker \& Thorpe 1982; Pinder \& Renshaw 2019; Velten, Ugrinowitsch, Portes, Hermann, \& Bläsing, 2016). 
Penney and Kidman (2014) claim that a TGfU informed approach is consistent with social constructivist theories of learning where coaches and athletes are all centrally involved in the learning process. I used a constructivist informed, humanistic approach to attempt to develop the players' autonomy and increase their ability to become independent decision makers (De Souza \& Oslin, 2008).

In turn, through continuous interactions with VI/Blind athletes, I found that coaching VI/Blind football enriched my coaching experience and liberated me from a limited, traditionalist perception of disability. In other words, VI/Blind football players guided me along the way as much as I guided them. This was a mutually inclusive and bespoke way of coaching football, which emphasizes the title of this paper 'the 'blind leading the blind' as I initially was blind to the nature and subtleties of VI/Blind football. Overall, coaching VI/blind football positively transformed my coaching style, knowledge, and philosophy and, most importantly, my perception of people with disability and disability sports. The organically emerging and athletes' needs informed and centred approach helped me move away from a traditional, medical model based and ocular-centric thinking towards a humancentred one, which placed emphasis on ability, skills and talent instead of impairment and disability.

\section{Conclusions}

In this article, we used the first author's personal experience in VI/Blind football to highlight some of the key challenges he faced at the early stages of his coaching career in disability sport. We explored the personal as well as structural challenges that were present and had to be contended with both as an individual and a coach. More importantly, we unpacked clear distinctions between coaching role related expectations and reality in VI/Blind football. We noted a significant gap in key skill sets and roles that the first author had to identify with, assume and develop in the field and in action. Considering that the dominant coaching paradigm was (and perhaps is) the ableist model, which focuses on the coach developing the physical attributes of players and athletes, the additional care and pastoral duties involved in coaching VI/Blind football posed numerous challenges to the first author. Negotiating infrastructural shortcomings, developing different coaching styles and strategies, along with assuming a support role were some of the chief tasks the first author had to carry out to successfully fulfil his role as an adapted football coach.

Consequently, through sharing the first author's personal experience, the main reason behind this article is to contribute to existing knowledge in the area of disability sports coaching and to encourage practitioners to reflect on the examples included therein and to make further, continued knowledge development contributions for the benefit of disability sports coaching.

\section{Perspectives}

In considering adapted physical activities and sports, it is pertinent to focus on the needs of the individuals involved in such activities. Whilst concentrating on the challenges athletes experience when undertaking adopted sports is central, we should not marginalise the experiences and needs of coaches who engage those athletes and ensure that they receive high quality support and sport/exercise experience. To understand the specific challenges coaches face in various disability sport settings, a more extensive array of qualitative, coachvoice centred, empirical evidence-based research strand is needed. Based on the selfnarrative presented in this paper, there are key areas and challenges identified that would require further exploration in a range of disability sports in regard to coaches' experiences and coach-athlete relations from a qualitative but multi-disciplinary angle. 


\section{Author affiliations:}

1 School of Sport and Exercise Science, University of Worcester, UK; d.mycock@worc.ac.uk; g.molnar@worc.ac.uk

* Correspondence: d.mycock@worc.ac.uk; Tel.: +44 1905855490

Author Contributions: Conceptualization, D.M. and G.M.; Methodology, G.M.; Formal Analysis, G.M. and D.M.; Writing Original Draft, D.M. and G.M.; Writing-Review and Editing, G.M.; Resources, D.M.

Funding: This research received no external funding

Acknowledgments: We would like to thank the reviewers and the editors for feedback and invaluable experience.

Conflicts of Interest: The authors declare no conflict of interest. the results.

\section{References}

Allan, V., Blair-Evans, M., Amy, E., Latimer-Cheung \& Cote, J. (2019). From the athlete's perspective: A social-relational understanding of how coaches shape the disability sport experience. Journal of Applied Sport Psychology, 32(6) 546-564. https://doi.org/39910.1080/10413200.2019.15875.51

American College of Sports Medicine. (2016). Exercise management for persons with chronic diseases and disabilities (3rd ed). Champaign IL: Human Kinetics.

Brittain, I. (2004). Perceptions of disability and their impact upon involvement in sport for people with disabilities at all levels. Journal of Sport and Social Issues, 28(4), 429452. https://doi.org/10.1177/0193723504268729

British Blind Sport. (2015). Strategic Direction and Targets for 2013 - 2017. Retrieved from http://www.britishblindsport.org.uk/files/2015-01-02/BBSStrategicPlan1317.pdf

British Blind Sport. (2017). Classification. Retrieved from http://www.britishblindsport.org.uk/classification/

British Blind Sport. (2019). History. Retrieved from www.britishblindsport.org.uk/about/history

Bunker, D., \& Thorpe, R. (1982). A model for the teaching of games in the secondary school. Bulletin of Physical Education, 18(1), 5-18.

Campos, C. (2000). Blind football. Scientific Congress (5th) Paralympic Games. International Paralympic Committee, Sydney, Australia.

Campos, L.F., Borin, J.P., Nightingale, T., Silva, A.A., Araújo, P.F., \& Gorla, J.I. (2014). Alterations of cardiorespiratory and motor profile of Paralympic 5-a-side football athletes during 14-week in-season training. International Journal of Sports Science, 4(6A), 85-90. https://doi/10.5923/s.sports.201401.12

Campos, L.F., De Athayde, A., Dos Santos, L., Costa, L.T., Montagner, P., Borin, J., \& Gorla, J. (2013). Effects of training in physical fitness and body composition of the Brazilian 5-a-side football team. Revista Andaluza De Medicina Del Deporte, 6(3), 9195. https://doi.org/10.1016/S1888-7546(13)70041-8

Carrington, B. (2008). What's that footballer doing here? Racialised performativity, reflexivity and identity. Cultural Studies, Critical Methodologies, 8(4), 423-452. https://doi.org/10.1177\%2F1532708608321574

Collins, M.F., \& Kay, T. (2003). Sport and social exclusion. Oxford: Routledge.

Cross, N., \& Lyle, J. (2006). The coaching process: Principles and practice for sport. Oxford: Butterworth-Heinemann.

Cushion, C.J. (2007). Modelling the complexity of the coaching process. International Journal of Sports Science and Coaching, 2(4), 395-401. https://doi.org/10.1260\%2F174795407783359650

Cushion, C.J. (2013). Applying game centred approaches in coaching: A critical analysis of the 'dilemmas of practice' impacting change. Sports Coaching Review, 2(1), 61-76. https://doi.org/10.1080/21640629.2013.861312

Davey, J. (2014). How do novice para sport coaches develop their knowledge? A look at the experiences of para sailing coaches. (Masters dissertation, University of Ottawa). Retrieved from https://ruor.uottawa.ca/bitstream/10393/30647/3/Davey Jennifer 2014 thesis.pdf. http://dx.doi.org/10.20381/ruor-3553 
Davies, T.C., Pinder, S.D., \& Burns, C.M. (2009). How far is that wall? Judging distance with audification. Proceedings of the Human Factors and Ergonomics Society Annual Meeting, 53(17), 1091-1095. https://doi.org/10.1177/154193120905301710

DePauw, K.P., \& Gavron, S.J. (2005). Disability sport (2nd ed.). Champaign, IL: Human Kinetics.

De Souza, A., \& Oslin, J. (2008). A player-centred approach to coaching. Journal of Physical Education, Recreation \& Dance, 79(6), 24-30. https://doi.org/10.1080/07303084.2008.10598195

Disability Living Foundation. (2019). Homepage. Retrieved from www.dlf.org.uk/content/full-list-factsheets

Disability Sports Coach. (2018). Homepage. Retrieved from www.disabilitysportscoach.co.uk

Elliott, J. (2006). Using narrative in social research. London: Sage.

English Federation of Disability Sport. (2016). Sport England's Active People Survey Disability. Retrieved from http://www.efds.co.uk/how445 wehelp/research/1986sport-england-active-people-survey-disability-aps10-factsheet

English Federation for Disability Sports. (2017). Facts \& statistics - English Federation for Disability Sport. Retrieved from http://www.efds.co.uk/how-we-help/fact-andstatistics

English Federation of Disability Sport. (2018). Homepage. Retrieved from http://www.efds.co.uk/

English Football Association. (2011). National Blind Futsal League Committee Meeting minutes from $24^{\text {th }}$ November. West Bromwich Albion FC, West Midlands, England.

European Blind Commission. (2020). Homepage. Retrieved from http://www.euroblind.org/about-blindness-and-partial-sight

European Commission. (2020). Employment, social affairs and inclusion. Retrieved from http://ec.europa.eu/social/main.jsp?catId=1137

Farias, A., Oliveira, C., Gonçalves, R., \& Sória, R. (2008). Desenvolvimento da aprendizagem do futebol para portadores de deficiência visual [Development of football learning for people with visual impairment]. Revista Mackenzie de Educação Física e Esporte, 7(3), 17-25.

Ferrara, M.S., \& Buckley, W.E. (1996). Athletes with disability injuries registry. Adapted Physical Activity Quarterly, 13(1), 50-60. https://doi.org/10.1123/apaq.13.1.50

Fortier, A-M. (2000). Migrant belongings: Memory, space, identity. Oxford: Berg.

Fister, I., Rauter, S., Xin-She Yang, Ljubic, K., \& Fister, I. Jr. (2015). Planning the sports training sessions with the bat algorithm. Neurocomputing. 149(B), 993-1002. https://doi.org/10.1016/j.neucom.2014.07.034

Fister, I., Fister, I. Jr., \& Fister, D. (2019). Computational intelligence in sports. Cham, Switzerland: Springer Nature.

Gamonales, J.M. (2016). Fútbol para personas ciegas y con deficiencia visual: "Un mundo sin descubrir" [Football for blind and visually impaired people: "An undiscovered world"]. In D. Gallardo, \& M. Urraco (Eds.), Catalogue of Young Research in Extremadura (chap. 29). Cáceres: Servicio de Publicaciones de la Universidad de Extremadura.

Gamonales, J.M., Muñoz-Jiménez, J., León-Guzmán, K., Sergio J., \& Ibáñez, S.J. (2018). 5a-side football for individuals with visual impairments: A review of the literature. European Journal of Adapted Physical Activity, 11(1), 4. https://doi.org/10.5507/euj.2018.004

Giagazoglou, P., Katis, A., Kellis, E., \& Natsikas, C. (2011). Differences in soccer kick kinematics between blind players and controls. Adapted Physical Activity Quarterly, 28(3), 251-266. https://doi.org/10.1123/apaq.28.3.251

Hedrick, B.N., Morse, M.I. \& Figoni, S.F. (1988). Training practices of elite wheelchair road racers. Adapted Physical Activity Quarterly, 5, 140-153. https://doi.org/10.1123/apaq.5.2.140

Horn, T.S. (2002). Coaching effectiveness in the sport domain. Champaign, IL: Human Kinetics. 
Horn, T.S. (2008). Coaching effectiveness in the sport domain. In: T.S. Horn (Ed.), Advances in sport psychology (3rd ed.) (pp. 239-267). Champaign, IL: Human Kinetics.

Houlihan, B., \& Malcolm, D. (2016). Sport and society (3rd ed.). London: Sage.

Hughes, C. (1980). The English Football Associations coaching book of soccer tactics and skills. London: Queen Anne Press.

IBSA. (2017). Football - General information. Retrieved from http://www.ibsasport.org/sports/football/

IBSA. (2017). History of IBSA. Retrieved from http://www.ibsasport.org/history/

IBSA. (2019). General information. Retrieved from https://www.ibsasport.org/sports/files/965-General-IBSA-Blind-Football-Rankingsas-of-1st-January-2019.pdf

International Council for Coaching Excellence and the Association of Summer Olympic International Federations. (2012). International Sports Coaching Framework, Version 1.1. Champaign, IL: Human Kinetics.

IPC. (2019). Classification. Retrieved from https://www.paralympic.org/classification

Jones, R.L. (2009). Coaching as caring (the smiling gallery): Accessing hidden knowledge. Physical Education and Sport Pedagogy, 14(4), 377-390. https://doi.org/10.1080/17408980801976551

Kasser, S.L., \& Lytle, R.K. (2013). Inclusive physical activity: Promoting health for a lifetime (2nd ed.). Champaign, IL: Human Kinetics.

King, S. (2019). In defence of realist tales. In A. Sparkes \& B. Smith (Eds.), Handbook of qualitative research in sport and exercise (pp. 291-301). Oxford: Routledge.

Kobberling, G., Jankowski, L.W., \& Leger, L. (1991). The relationship between aerobic capacity and physical activity in blind and sighted adolescents. Journal of Visual Impairment and Blindness, 85, 382-384. https://doi.org/10.1177\%2Fo145482X9108500909

Le Clair, J.M. (2011). Global organizational change in sport and the shifting meaning of disability. Sport in Society, 14(9), 1072-1093.

https://doi.org/10.1080/174304.37.2011.614765.10.1080/17430437.2011.614765

Lenney, M., \& Sercombe, H. (2002). Did you see that guy in the wheelchair down the pub?' Interactions across difference in a public place. Disability \& Society, 17(1), 5-18. https://doi.org/10.1080/09687590120100093.10.1080/09687590120100093

Macbeth, J.L. (2009). Restrictions of activity in partially sighted football: Experiences of grassroots players. Leisure Studies, 28(4), 455-467. https://doi.org/10.1080/02614360903071696

Martin, J. (1999). A personal development model of sport psychology for athletes with disabilities. Journal of Applied Sport Psychology, 11(2), 181-193. https://doi.org/10.1080/10413209908404199

Martin, J., \& Whalen, L. (2014). Effective practices of coaching disability sport. European Journal of Adapted Physical Activity, 7(2), 13-23. https://doi.org/10.5507/euj.2014.007

Matsui, R. (2007). First Brazilian school games by the Brazilian Confederation of Sports for blind people: A study of case. Brazil: University Estudal de Campinas. Faculty of Physical Education. Retrieved from http://repositorio.unicamp.br/jspui/handle/REPOSIP/275221

McMaster, S., Culver, D., \& Werthner, P. (2012). Coaches of athletes with a physical disability: a look at their learning experiences. Qualitative Research Exercise and Health, 4(2), 226-243. https://doi.org/10.1080/2159676X.2012.686060.10.1080/2159676X.2012.686060

Moore, G.E, Durstine, J.L, Painter, P.L., \& Roberts, S.O (2016). ACSM’s exercise management for persons with chronic diseases and disabilities (3rd ed.). Champaign, IL: Human Kinetics.

Morato, M.P. (2007). Football for blind people (football of five) in Brazil: Understanding of the game and strategies tactic and techniques. Dissertation (Masters in Physical Education). Brazil. Retrieved from http://repositorio.unicamp.br/jspui/handle/REPOSIP/275176 
Morato, M.P., Gomes, M.S.P., Duarte, E., \& De Almeida, J.J.G. (2011). A leitura de jogo no futebol para cegos [Lecture on blind football player movements]. Movimento, 17(3), 97-114. Retrieved from: https://doi.org/10.22456/1982-8918.17261

Mosston, M., \& Ashworth, S. (1986). Teaching physical education. Columbus, OH: Merrill. Papworth Trust. (2019). Homepage. Retrieved from http://www.papworthtrust.org.uk

Peers, D. (2012). Interrogating disability: The (de)composition of a recovering Paralympian. Qualitative Research in Sport, Exercise and Health, 4(2), 175-188. https://doi.org/10.1080/2159676X.2012.685101

Penney, D., \& Kidman, L. (2014). Promoting and supporting coaches' professional learning: Developing a community of practice. The Journal of Athlete Centred Coaching, 1(1), 6-31.

Pill, S. (2012). Teaching game sense in soccer. Journal of Physical Education, Recreation \& Dance, 83(3), 42-52. https://doi.org/10.1080/07303084.2012.10598746

Pinder, R.A., \& Renshaw, I. (2019). What can coaches and physical education teachers learn from a constraints-led approach in para-sport? Physical Education and Sport Pedagogy, 24(2), 190-205. https://doi.org/10.1080/17408989.2019.1571187

Polanyi, M. (1970). Personal knowledge: Towards a post-critical philosophy. Morgantown: Fitness Information Technology.

Ponchillia, P., Armbruster, J., \& Wiebold, J. (2005). The National Sports Education Camps Project: Introducing sports skills to students with visual impairments through shortterm specialised instruction. Journal of Visual Impairment and Blindness, 99(11), 685-695. https://doi.org/10.1177\%2F0145482X0509901107

Ponchillia, S.V., Powell, L.L., Felski, K.A., \& Nicklawski, M.T. (1992). The effectiveness of aerobic exercise instruction for totally blind women. Journal of Visual Impairment \& Blindness, 86(4), 174-177. https://doi.org/10.1177\%2F0145482X9208600404

Reilly, T. (ed.). (2008). Science and sports: Bridging the gap. Shaker, Netherlands: World Commission of Science and Sports.

Royal National Institute for the Blind. (2019) Mobility training and spatial awareness. Retrieved from https://www.rnib.org.uk/young-people-leaving-home/life-skillstravel-and-mobility

Schmidt, R.A., \& Wrisberg, C.A. (2014). Motor control and skill acquisition ( $5^{\text {th }}$ ed.). Champaign, IL: Human Kinetics.

SCOPE. (2019). Homepage. Retrieved from http://www.scope.org.uk

Short, F., \& Winnick, J. (1986). The influence of visual impairment on physical fitness test performance. Journal of Visual Impairment and Blindness, 8o(5), 729-731.

Sports Coach UK. (2017). Inclusive Coaching. Retrieved from http://www.sportscoachuk.org/coaches/resource-bank/inclusive-coaching.

Sport England. (2017) Active Lives Adult Survey. Retrieved from https://www.sportengland.org/media/12458/active-lives-adult-may-16-17-report.pdf

Sport England. (2018) Why disability sport matters. Retrieved from https://www.sportengland.org/our-work/disability-sport/why-disabilitysportmatters/

Stewart, A. (2016). The boxer in the mirror. In: G. Molnar \& L.G. Purdy (Eds.), Ethnographies in sport and exercise research (pp. 111-125). Oxford: Routledge.

Sugden, J.S., \& Tomlinson, A. (2002). Power games: A critical sociology of sport. London: Taylor \& Francis.

Tawse, H., Bloom, G.A., Sabiston, C.M., \& Reid, G. (2012). The role of coaches of wheelchair rugby in the development of athletes with a spinal cord injury. Qualitative Research in Sport, Exercise and Health, 4(2), 206-225. https://doi.org/10.1080/2159676X.2012.685104.10.1080/2159676X.2012.685104

The English FA. (2017). Coaching players with disabilities Courses. Retrieved from http://www.thefa.com/get-involved/coach/courses/all-courses/coaching-playerswithdisabilities

The English FA. (2017). Disability football performance pathway: From grassroots to the elite game. Retrieved from

http://www.thefa.com/getinvolved/player/disability/performance-pathway 
The English FA. (2017). FA responds to blind football's funding cuts by UK Sport. Retrieved from http://www.thefa.com/news/2014/Mar/19/uk-sport-blind-footballfunding-jeffdavis

The English FA. (2019). Disability football overview. Retrieved from www.thefa.com/getinvolved/player/disability

The Royal National College for the Blind. (2019). Homepage. Retrieved from https://www.rnc.ac.uk

Thorpe, R., Bunker, D., \& Almond, L. (Eds.). (1986). Re-thinking games teaching. Loughborough: University of Technology.

Townsend, R.C., Smith, B., \& Cushion, C.J. (2019). Disability sports coaching: Towards a critical understanding. Sports Coaching Review, 4(2), 80-98. https://doi.org/10.1080/21640629.2016.1157324

Velten, M.C., Ugrinowitsch, H., Portes, L.L., Hermann, T., \& Bläsing, B. (2016). Auditory spatial concepts in blind football experts. Psychology of Sport and Exercise, 22, 218228. https://doi.org/10.1016/j.psychsport.2015.08.010

Wade, A. (1967). The FA guide to training and coaching. London: Heinemann.

Wareham, Y., Burkett, B., Innes, P., \& Lovell, G.P. (2017). Coaching athletes with disability: Preconceptions and reality. Sport in Society, 2O(9), 1185-1202. https://doi.org/10.1080/17430437.2016.1269084

Weinberg, R.S., \& Gould, D. (2019). Foundations of sport and exercise psychology $\left(7^{\text {th }}\right.$ Ed.). Champaign, IL: Human Kinetics.

Willis, P. \& Trondman, M. (2000). Manifesto for ethnography: Cultural Studies. Critical Methodologies, 2(3), 394-402. https://doi.org/10.1177/14661380022230679

Young, J.A. (2010). The state of play: Coaching persons with disabilities. ITF Coaching and Sport Science Review, 5o(18), 9-10. BY) license (http://creativecommons.org/licenses/by/4.o/). 